\title{
Taiwan's 228 Incident and the Politics of Placing Blame
}

Craig A. Smith, University of British Columbia

On February 28, 1947, an uprising began and was followed by the massacre of thousands of ethnic Taiwanese. Although the memory of this massacre was suppressed by forty years of martial law, it has recently become an important socio-political symbol in modern Taiwan. The construction of the symbolic mythology of the 228 Incident has remade the massacre as an important historical event and $a$ divisive tool in the political and ethnic turmoil of Taiwan. This paper examines the event of the 228 Incident and determines how the incident has been mythologized in modern political discourses due to its recently acquired symbolic status in Taiwan's history. The paper pays particular attention to interpretations and reactions of Taiwan's two major political parties.

February 28, 2007 marked the sixtieth anniversary of the 228 Incident, ${ }^{1}$ an uprising on Taiwan which was brutally suppressed with the massacre of thousands, and perhaps tens of thousands, of civilians by Kuomintang ${ }^{2}$ (KMT國民黨) troops. The academic

\footnotetext{
${ }^{1}$ In academic writing the 228 Incident (read as two-two-eight) is also often known as the February 28 Incident or the Formosa Uprising. I choose to use the 228 Incident as this English name has become more popular in recent years and is a direct translation of the Chinese name Er er ba Shijian 二二八事件.

${ }^{2}$ The Romanization of Chinese characters is always a frustrating and complicated issue. I have primarily adhered to the popular pinyin system with some important exceptions. The names of writers and artists from Taiwan are written in the Wade-Giles system, which is still commonly used for publications of works from Taiwan. For the names of people and places that are already established in
} 
world commemorated the event with the hosting of conferences on the subject, most of which were in Taiwan, but some were even held as far away as Sweden, where a conference was hosted by London University's School of Oriental and African Studies. In Taiwan, where the day has been a national holiday since 1996, numerous commemorative events were held across the island, 144 most of them by the Democratic Progressive Party（民進黨 DPP). ${ }^{3}$ The DPP has taken possession of "Peace Memorial Day" (和平紀念日) as a day to remember the violence caused by the KMT. The KMT has no choice but to be on the defensive at such commemorations. In 2007, responsibility was the foremost topic with the DPP pinning the responsibility on late dictator Chiang Kai-shek 蔣介石 and pulling down his statues across the island. The KMT has refused this perspective, but will likely be unable to stop the continued denouncements of Chiang, which even led to the Executive Yuan's renaming of Taiwan's most well-known monument, Chiang Kai-shek Memorial Hall (中正紀念堂), as Taiwan Democracy Memorial Hall (台灣民主紀念館) in 2007. ${ }^{4}$ The quest to determine responsibility remains an important and

English-language publications, I have tried to adhere to their preferred or most popular spellings. The initial occurrence of all Chinese names and terms is followed by the original Chinese characters in traditional script.

${ }^{3}$ Politics in Taiwan, which is formally called the Republic of China, are dominated by two political parties: The Kuomintang and the Democratic Progressive Party. The KMT led Taiwan from the time of its retrocession to China in 1945 until they lost the second direct presidential election in 2000. They had won the first election in 1996. The DPP led Taiwan through two terms from 2000 to 2008. On March 22, 2008, Ma Ying-jeou, chairman of the KMT, won the fourth presidential election, regaining the KMT's position as the party in power.

${ }^{4}$ However, before the 2008 election Ma Ying-jeou promised to restore its former name if elected. Ma became president in May of 2008, although at the time of writing he had not yet taken steps to do so.

Past Imperfect

14 [2008] | (C) |ISSN 1711-053X| eISSN 1718-4487 
controversial debate with numerous opposing perspectives on an event that took place more than sixty years ago.

This paper considers the events and circumstances surrounding the 228 Incident and determines how the incident has been mythologized by later generations, especially through Taiwan's politics since the 1980 s, due to its symbolic status in the history of the so-called Republic of China on Taiwan. The construction of the symbolic mythology of the 228 Incident has made the uprising an important historical event and a divisive tool in the political and ethnic turmoil of contemporary Taiwan. By examining the incident as it is seen, first by historians, then by politicians, I will show how the mythologization process has centred, in this arena, on the charging of responsibility. As Jeffrey C. Alexander states, "[I]n creating a compelling trauma narrative, it is critical to establish the identity of the perpetrator, the "antagonist." "S Since the end of martial law in 1987, the DPP has managed to successfully tie itself to the remembrance of the 228 Incident, a critical move in its political aspirations. An effective trauma narrative with Chiang Kai-shek as its antagonist has been constructed. During this same time period, the KMT have been forced to evolve considerably in order to ensure that the implications of such a narrative no longer have the efficacy they once held in the political arena.

The importance of the 228 Incident cannot be underestimated by politicians in Taiwan. In the divisive politics of the island, the symbolism of a massacre perpetrated by mainlanders against Taiwanese is of crucial importance. And the

\footnotetext{
5 Jeffrey C. Alexander, "Toward a Theory of Cultural Trauma," in Jeffrey C. Alexander, et al, (Eds), Cultural Trauma and Collective Identity (Berkeley: University of California Press, 2004), 15. 
use of this massacre in Taiwanese politics and nationalism as a sacred and sensitive event that binds Taiwanese together and divides them from the mainlanders makes the incident an important topic for historians. It is strange then to see that it has been ignored by many. In Immanuel Hsü's lengthy The Rise of Modern China, it is treated in a single paragraph. ${ }^{6}$ The same pithy 146 coverage of the Incident is evident in Jonathan Spence's The Search for Modern China. ${ }^{7}$ However, both these books have a chapter on Taiwan, focusing instead on the economic "miracle" of modern Taiwan. In John F. Copper's widely-read political science text, Taiwan: Nation-State or Province?, one would imagine the incident would find more importance. However, it is only briefly mentioned on three pages and incorrectly states that the incident that triggered the uprising was "when plainclothes police officers killed a Taiwanese woman who had been selling black-market cigarettes. ${ }^{\prime 8}$ However, it was bystander Chen Wenxi (陳文溪), not cigarette seller Lin Jiangmai (林江邁) who was killed. It seems that these eminent authors of Taiwan's past have not kept up with the 228 Incident's importance in the present. Therefore, it is necessary to first consider a brief account of the events that occurred in 1947.

\section{The 'Incident'}

\footnotetext{
${ }^{6}$ Immanuel C.Y Hsü, The Rise of Modern China (Sixth Edition) (New York: Oxford University Press, 2000), 739.

${ }^{7}$ Jonathan D. Spence, The Search for Modern China (New York: W.W. Norton and Company, 1999), 485.

${ }^{8}$ John F. Copper, Taiwan: Nation-State of Province (Fourth Edition), (Boulder: Westview Press, 2003), 44 - 46.
}

$$
\begin{gathered}
\text { Past Imperfect } \\
14 \text { [2008) | ( ) |ISSN 1711-053X | elSSN 1718-4487 }
\end{gathered}
$$


Since the establishment of Nationalist rule on October $25^{\text {th }}, 1945$, the economic and social situation in Taiwan had worsened considerably. Despite early efforts by the Kuomintang to prepare for the retrocession of Taiwan, ${ }^{9}$ the Nationalists had neither the experience, nor the personnel resources to govern Taiwan with the same level of efficiency and stability managed by the Japanese government. ${ }^{10}$ Furthermore, the deterioration of the situation on the mainland as the civil war deepened consumed all the attention of top KMT officials, and drained resources from Taiwan.

The incident that triggered the riots is a relatively minor, but now very famous event. On the evening of Thursday February 27, 1947, an old woman was found selling illegal cigarettes by officers of the Monopoly Bureau outside the Tianma Tea Store on Taiping Street (now Yanping Street) in Taipei City. As they attempted to arrest the woman, a crowd gathered. In the confusion that followed, an officer shot and killed one of the people. Although the officers were able to escape from the scene, the enraged crowd marched to the local police office to demand the execution of the shooter. ${ }^{11}$

Word of the incident spread quickly and deliberately. The protesters demanded that newspapers publish the event, even

9 The Kuomintang began serious preparations for the rule of Taiwan after the Cairo Declaration of 1943. Lai, Myers, Wou, A Tragic Beginning: The Taiwan Uprising of February 28, 1947 (Stanford: Stanford University Press, 1991), 5657. As it is still the finest English-language text on the 228 Incident, I have cited A Tragic Beginning numerous times. However, it should be noted that this book, like any on the incident, is often accused of being biased. Many have accused it of having a bias in favor of the KMT.

10 The size of the Early ROC bureaucracy on Taiwan was only half that of Japan's of two years earlier. The military and police forces on Taiwan were only 6.4 percent of what Japan had stationed on Taiwan. Ibid., 65 .

${ }^{11}$ Ibid., 102-103.

$$
\begin{gathered}
\text { Past Imperfect } \\
14 \text { [2008] | @ | ISSN 1711-053X | elSSN 1718-4487 }
\end{gathered}
$$


though the Propaganda Commission had already ordered them not to do so. By the next day, February $28^{\text {th }}$, it was already clear that public anger was due to more than just this incident of brutality by the Monopoly Bureau. Protesters occupied a Taiwan radio station and broadcast information about the event across Northern Taiwan, inciting violence towards mainlanders and calling for 148 people to gather in Taipei's New Park to march on the Provincial Administration Executive Office. ${ }^{12}$ This march terrified the few police left to defend the office, who fired into the crowd, killing two and wounding others. Known as the Guangchang (廣場事件 The Incident at the Square), this was a pivotal point in the protests, confirming the beliefs of many Taiwanese that the mainlanders, as represented by the KMT government in Taiwan, did not value the residents.

Violence against mainlanders spread across the island. As demonstrated in Hou Hsiao-hsien's iconic film, Bei qing chengshi (悲情城市 City of Sadness 1989), ${ }^{13}$ Taiwanese would speak to strangers in Japanese, Taiwanese or Hakka to determine whether or not they were mainlanders. If they could not respond, the victims were beaten, often fatally. Many mainlanders were caught unaware and had no idea why they were being attacked, while others quickly fled the cities. In total, more than one thousand mainlanders were killed in violent attacks. ${ }^{14}$ Although the rioting began in confusion, as calm returned to the cities, the Resolution

\footnotetext{
${ }^{12}$ In this paper, the term 'mainlander' refers to those who came to Taiwan from mainland China after the retrocession. 'Taiwanese' refers to those whose families came to Taiwan earlier from Fujian Province and made up the vast majority of the population in 1947.

${ }^{13}$ Zhu Tianwen 朱天文, Bei qing cheng shi 悲情城市 [City of Sadness], DVD, directed by Hou Hsiao-hsien 侯孝賢 (Taiwan: 3-H Films/Era, 1989).

${ }^{14}$ Ibid., 141.
} 
Committee that was established in Taipei City began to set up organizations across the country in the hopes of maintaining safety and order. The central Resolution Committee in Taipei then began issuing demands to Kuomintang governor Chen Yi. The demands changed as the movement evolved from street protests towards rebellion. As the committee's confidence increased, the demands requested more and more political autonomy, until the troops arrived and ended all talk of resolution.

Even before the troops reached the shore they began shooting. Once in the cities, the soldiers shot indiscriminately at anyone on the street. This was especially true in Keelung, Taipei, Chiayi, and Kaohsiung, where fighting was at its worst. This terrifying method of controlling rebellions was standard for the Kuomintang, who had been desperate in their fights on the mainland for many years. However, the policy went to a new extremes in Taiwan as the battle-hardened troops were facing the frustration of a language barrier in their attempts to control the Taiwanese. The worst of the violence lasted from March 12 to May 15. The number of lives lost has been hotly debated, ranging from Pai Ch'ung-hsi's (白崇禧) low estimate of under 2000 to the high estimates by Taiwanese organizations in Japan and the United States with some numbers as high as $100,000 .{ }^{15}$ Lai Myers and Wou, taking into account a variety of sources, believe the number may be fewer than 10,000, consisting mostly, but not

\footnotetext{
${ }^{15}$ A number of organizations and their estimates are listed in Lai Zehan, et al, A Tragic Beginning: The Taiwan Uprising of February 28, 1947 (Stanford: Stanford University Press, 1991), 158, 244.

Past Imperfect 14 [2008) | (C) ISSN 1711-053X| | ISSN 1718-4487
} 
entirely, of Taiwanese urban elite. ${ }^{16}$ As with any massacre in history, the estimates of the number killed is an emotional subject that is often a fast and easy way to capture newspaper headlines. Li Ao (李教), a writer and politician who frequently uses sensational means to get in the news (including in 2006, the act of bringing a life-size nude photo of himself to the Legislative Yuan 150| and the act of spraying tear gas in the same building months later), made use of the highly emotional number game to gain headlines in 2007 , claiming that only 800 people had actually been killed during the 228 Incident. ${ }^{17}$ News media in Taiwan tend to choose either 20,000 or 30,000 as the acceptable figure.

\section{Accounting for the Massacre}

When the Kuomintang forces arrived in Taiwan in 1945, they had been fighting against the Japanese for eight years. This war had drained their resources and their spirits. However, Taiwan had been under Japanese colonial rule since 1895 and great efforts had been made to assimilate the Taiwanese into Japanese culture. Therefore, in the eyes of the Kuomintang forces, the Taiwanese had been collaborating with the enemy, were tainted and not to be trusted. The other great enemy for the Kuomintang was the communists. Chiang Kai-shek was intent on destroying the communist strongholds on the mainland at that time, and could not afford for any organization of them in Taiwan. The involvement of Hsieh Hsueh-hung in the leadership of the Taichung faction unfortunately brought strong emotions against

\footnotetext{
${ }^{16}$ Ibid., 157-159.

${ }^{17}$ Shih Hsiu-chuan, "Hardline Academics Blame Japan for 228 Incident," Taipei Times, 8.258, February 28th, 2007.

Past Imperfect 14 [2008] | (C) |ISSN 1711-053X | eISSN 1718-4487
} 
the rebellion. Although the involvement of the communists was clearly very limited, KMT governor Chen Yi had advised Chiang Kai-shek that they were to blame, perhaps in order to draw attention away from other reasons for the rebellion which may have easily been associated with his mismanagement of the colony. As far as the military was concerned, the presence of a communist threat made Taiwan not unlike areas on the mainland where they had been fighting the civil war. The Kuomintang army then attacked with swift ferocity in order to secure the island quickly and enable the troops to continue the war on the mainland. March 1947 was a crucial month in the campaign on the mainland as the Kuomintang had seized Yan'an, and, in a burst of optimism, Chiang Kai-shek told American ambassador, John Leighton Stuart that the Communists would be totally defeated, or at the least driven far back by August or September. ${ }^{18}$ So the Kuomintang forces fighting on Taiwan were operating under fear, a sense of urgency, hatred for the Japanese, hatred for the Communists, and, for at least some, revenge. The forces stationed on Taiwan at the time of the uprising may have had friends or even family members attacked by the Taiwanese mobs, and even those who did not would have felt frustrated by their impotence to stop the violence. Although Chiang Kai-shek had clearly warned Chen Yi to instruct the soldiers not to act in revenge, it remains apparent that some still did so. ${ }^{19}$

On their part, the Taiwanese had also entered this situation with enmity towards the mainlanders. The jubilation with which they had first met the boats of the Kuomintang in

\footnotetext{
${ }^{18}$ Immanuel C.Y. Hsu, The Rise of Modern China (Sixth Edition), (New York: Oxford University Press, 2000), 630.

${ }^{19}$ Lai Zehan, et al, A Tragic Beginning, 152. 
1945 had fast disappeared as the people became aware of the corruption and inexperience of the bureaucracy. The Taiwanese viewed the mainlanders as ignorant and were frustrated with the weak bureaucracy that was operating at a bare minimum in order to keep human resources at work in the mainland. The Taiwanese also saw their social services, such as healthcare deteriorate, as

152 diseases spread across the island. Mainlanders were of course held to blame for any epidemic the Taiwanese became aware of. As both public and private buildings were stripped to support the war efforts, the Taiwanese were made completely aware of the depletion of their island's resources. And the rising cost of rice was felt by everyone, as food was shipped across the straits.

Politically, the Taiwanese were also frustrated as mainlanders were awarded all the higher government positions and Taiwanese were paid on a lower scale than their mainland counterparts. All of these pressures were enough to convince the Taiwanese to act when the situation arose. However, there was no initial organization to the uprising. The majority of the people involved were venting their fury at the Kuomintang and the mainlanders, but had not agreed to any concept of rebellion. Perhaps the rioting represented the anger of the people, but it is not as easy to determine whether or not the Resolution Committee's demands for greater self-governance represented the will of the people, or whether this was a reaction from the Taiwanese elite.

\section{The Political Parties}

The events surrounding the 228 Incident were terrible, yet complicated, leaving plenty of room for interpretation. 
Furthermore, the Kuomintang's efforts to suppress dialogue or commemoration of the massacre resulted in a lack of definitive information on the circumstances surrounding the incident, but also served to ensure that there would be an emotional outpouring when the period of White Terror ${ }^{20}$ came to an end and the victims and their families were free to speak. The political parties involved have all had to find ways to interpret this event. The KMT have had to find ways to capture the people's trust more than fifty years after the event while the Democratic Progressive Party has moved to take political advantage of the incident. The Chinese Communist Party has heralded the incident as an exclamation of the will of the people. However, in the case of the Chinese Communist Party on the mainland, the 228 Incident has not been as important to their continued success; therefore, there has been little if any divergence from their initial interpretation of the event. On the $28^{\text {th }}$ anniversary of the uprising, the Beijing government released a statement linking the incident to the many pro-communist uprisings that occurred on the mainland during the 1940 s and stated that the Taiwanese people found their inspiration in Chairman Mao. ${ }^{21}$

Such an outlook is useful for the CCP in reaffirming its claim on Taiwan, as well as the continued propagation of the grand narrative of the people's united march towards a socialist utopia. The CCP has had little reason to make continued remarks on the 228 Incident or to change the stance it established in

\footnotetext{
${ }^{20}$ The White Terror refers to the decades after the 228 Incident in which those believed to be in opposition to the Kuomintang, or in sympathy with communists, were imprisoned or executed. The White Terror is thus limited to the years of martial law, which stretched from 1948 to 1987.

${ }^{21}$ Lai Zehan, et al, A Tragic Beginning, 3. 
1975. Supporters of communism from Taiwan have, however, continued with this myth, or at least indirectly supported it. The well-known socialist writer, Ch'en Ying-chen (陳映真), was brave enough to write about the White Terror before the lifting of martial law. In what may be his best-known and most anthologized work in the West, "Mountain Path" (山路), 154 although avoiding any dangerously explicit remarks, Ch'en indicates the victims of the Kuomintang's purging campaigns were socialists, fighting for the Taiwanese working class and hoping for the success of the revolution on the mainland.

\section{The Rise of the Democratic Progressive Party}

The DPP has clearly gained the most from the use of the 228 Incident. The Taiwanese Independence Movement (TIM) captured the symbolic power of the incident in their struggle for independence, citing the massacre to highlight the conflict between Taiwanese and mainlanders. This movement had a strong impact on the early DPP. Although there had been calls for an independent Taiwan throughout the Japanese occupation period (1895 -1945), and even before, many people consider its real birth to be the formalization of the Alliance for the Re-liberation of Taiwan (台灣再解放同盟 Taiwan zaijiefang tongmeng), an association started by the Liao brothers, Thomas and Joshua, in 1948 after they escaped from the post-February 28 crackdowns, and found refuge in Japan. ${ }^{22}$ The TIM considers the 228 Incident as a part of a history of struggle towards independence, as

\footnotetext{
${ }^{22}$ Lai Zehan, et al, A Tragic Beginning, 189.

Past Imperfect 14 [2008) | (C) |ISSN 1711-053X| elSSN 1718-4487
} 
explained in Taiwan seinen's (Taiwan Youth) February 20, 1961 issue:

The flowing tide for an independent Taiwan began with the National People's Movement in 1920, and continued with the efforts to abrogate the June 3, 1896, law, the movement to establish a Taiwan Parliament, and the awakening of the masses of farmers and workers. Therefore, the Uprising of the Taiwanese people on February 28, 1947, [was] merely a continuation of that great tide... Naturally, this Uprising was a sacred struggle based upon the people's just demands for their fundamental rights. ${ }^{23}$

Although the DPP is certainly not the TIM, the organizations share common ground. The viewpoint of the previous ROC president and former leader of the DPP, Chen Shui-bian (陳水扁), was not far from this interpretation, but his emphasis was centred more upon laying blame squarely on the KMT. Chen managed to strongly associate the DPP with the incident, particularly with his renaming of Taipei's New Park to 228 Peace Park in 1996, when he was the mayor of Taipei City. His more recent comments on the incident were aggressive attacks on the KMT. Speaking at the 2006 commemoration in 228 Peace Park, he said, "Over the past 20 years, some have tried to simplify, twist or even falsify the historical meaning of the incident, saying that it was a social uprising caused by government corruption, but that is not true. It is a false history fabricated for political purposes." Refuting the KMT interpretation of February $28^{\text {th }}$, Chen argues that it was "a systematic slaughter and organized suppression of Taiwanese

\footnotetext{
${ }^{23}$ Translated from the Japanese language journal by Lai Zehan, et al, A Tragic Beginning, 4.

Past Imperfect 14 [2008) | @ |ISSN 1711-053X| elSSN 1718-4487
} 
people," carried out by "a foreign administration and authoritarian regime to consolidate its power." ${ }^{24}$ With statements such as this, Chen captured the symbolic power of the incident.

The rise of the DPP was necessarily concurrent with the liberalization of Taiwan and the KMT's relaxing of restrictions on one party rule, which formally allowed the DPP legal 156| formation in $1989 .{ }^{25}$ Throughout the 1980 s and 1990s popular protest pushed for more liberalization on Taiwan, allowing for an exploration of 228-awareness for a generation that had been largely ignorant of such events. This is perhaps best exemplified by the tremendous popularity of Hou Hsiao-hsien's film, Bei qing cheng shi. The popularity of the film ensured that people across Taiwan were aware of the 228 Incident, provoking dialogue and shattering the silence. Michael Berry describes Bei qing cheng shi as "unquestionably the cultural event in Taiwan during the late 1980s." ${ }^{26}$ This strong statement shows the importance of the 228 Incident to the culture of Taiwan during the identity forming years after martial law. This was a cultural movement which the DPP was very much a part of, and which the KMT struggled to come to terms with.

\footnotetext{
${ }^{24}$ Shui-ling Ko, "Chen urges truth of 228 Incident to be remembered," Taipei Times, 1 Mar. 2006

$<$ http://www.taipeitimes.com/News/front/archives/2006/03/01/2003295137>

${ }^{25}$ However, the DPP had formally announced its establishment in 1986, when dangwai (黨外 those outside of the party) leaders met at the Grand Hotel in Taipei. Consistent street rallies and the popularity of the dangwai leaders provided sufficient pressure to stop the government from arresting those involved in the illegal political party. See Denny Roy, Taiwan: A Political History (Ithaca: Cornell University Press, 2003), 170-172.

${ }^{26}$ Michael Berry, "Screening 2/28: From a City of Sadness to a March of Happiness," in The Proceedings of Taiwan Imagined and Its Reality - An Exploration of Literature, History, and Culture (Santa Barbara: Center for Taiwan Studies, 2005), 51.
}

$$
\begin{gathered}
\text { Past Imperfect } \\
14 \text { [2008) | (C) |ISSN 1711-053X | elSSN 1718-4487 }
\end{gathered}
$$




\section{Change in the Kuomintang}

For the Kuomintang, the official position on the incident was established by Pai Ch'ung-hsi's (白崇禧) report to Chiang Kaishek made after his visit in March of 1947. Pai concluded that the people were easily misled due to their "evil education from the Japanese," and were duped by communist organizers. ${ }^{27}$ This analysis justified the use of extreme violence during the uprising and throughout the period of White Terror. However, once martial law was lifted in 1987, the 228 Incident became a political thorn for the KMT and an important piece of propaganda for the DPP. In damage control the KMT had to alter its view on the tragedy and find a more apologetic stance that displaced the blame from the party itself to a few individuals. Chen Yi, long since executed as a traitor, ${ }^{28}$ became a plausible scapegoat.

Kuomintang official policy on the incident has since been that the uprising was a result of corruption among officials, and unruly soldiers and local officials were to blame for the ensuing violence. Historians have long accepted Chen $\mathrm{Yi}$ as the one deserving blame for the incident. ${ }^{29}$ This of course indicates some KMT responsibility, and, as tension between the DPP and the KMT intensified, an apology was necessary. Lee Teng-hui

${ }^{27}$ Ibid., 5.

${ }^{28}$ Chen Yi was executed on June 18, 1950, after Chiang discovered he was making arrangements to hand over territory to the communists. Fred W. Riggs, Formosa Under Chinese Nationalist Rule (New York: The Macmillan Company, 1952), 44.

${ }^{29}$ Although Jonathan Spence never mentions the incident by name, he does make reference to "the riots and massacres sparked by Chen Yi in 1947." Jonathan D. Spence, The Search for Modern China (New York: W.W. Norton and Company, 1999), 500. Hsü, The Rise of Modern China, 750. 
(李登輝), the ethnic Taiwanese leader of the KMT and president of the Republic of China from 1988 to 2000, made a public apology for the 228 Incident in 1995. Lee was a very popular leader who managed to find supporters among both the mainlanders and the Taiwanese. He was very apologetic for what he called "a case of the severe oppression of Taiwanese by the 158| KMT government." ${ }^{30}$ This differs from Ma Ying-jeou (馬英九), who became president in May, 2008. Ma still follows the party understanding, stating that the guilt should fall on local leaders and not on Chiang Kai-shek, but has decided not to continue with public apologies. ${ }^{31}$

Speaking on February $28^{\text {th }} 2007$, Ma stressed that the 228 Incident was a political uprising and definitely not, as the Democratic Progressive Party claim, an ethnic conflict. Ma's reluctance to apologize for the massacre emphasizes that the KMT of today is not the KMT of 1947. The liberalization of Taiwan that spanned the 1980 s and 1990s under presidents Chiang Ching-kuo and Lee Teng-hui also resulted in great change for the party, which is no longer seen as an entity entirely controlled by mainlanders and in opposition to Taiwan's interests. Confrontation and competition with the dangwai and the DPP have led the KMT closer to the political centre on Taiwan. Therefore, the simple association of the KMT with the 228 Incident no longer holds the persuasive strength it once did. As the KMT returned to a position of power in 2008 , the symbolism

\footnotetext{
${ }^{30}$ Lee Teng-hui. The Road to Democracy: Taiwan's Pursuit of Identity (Tokyo: PHP Institute, 1999), 35.

${ }^{31}$ Mo, Yan-chih. "No Apologies at KMT's 228 Ceremony," Taipei Times, 26 Feb. 2006

$<$ http://www.taipeitimes.com/News/front/archives/2006/02/26/2003294695>

Past Imperfect

14 [2008) | ( ) |ISSN 1711-053X | elSSN 1718-4487
} 
of the 228 Incident, as employed by Chen Shui-bian years earlier, is significantly diminished.

\section{Conclusion}

In 2006 the $59^{\text {th }}$ anniversary of the 228 Incident was accompanied by the latest and most heavily researched volume on the uprising. Newly declassified documents and a wide range of personal accounts allowed for researchers from Academia Sinica to detail the events like never before, and, more importantly for many of those mired in the chaotic world of Taiwan's politics, determine who among the high-ranking Kuomintang officials could be found responsible for the deaths of thousands of Taiwanese. The report was called "Research Report for Responsibility on the 228 Massacre" (二二八事件責任歸屬研究報告 Ererba shijian zeren guishu yanjiu baogao) and was commissioned by the DPP government on Taiwan. The publication of this highly contentious report captured a large audience as it made use of newly released classified correspondence to pin the blame on Chiang Kai-shek. The report was immediately heralded by the DPP and denounced by some conservative KMT politicians, as one KMT legislator, John Chiang (蔣孝嚴), the grandson of Chiang Kai-shek, announced plans to sue the publishers and researchers for slander. ${ }^{32}$

In 2007 John Chiang also threatened to sue Chen Shuibian over his many defamatory comments on Chiang Kai-shek. In the year that followed the publication of the "Research Report

\footnotetext{
${ }^{32}$ Erik Mobrand, “Taiwan Remembers Feb. 28 Incident,” World Press.org, 1 Mar. $2006<$ http://www.worldpress.org/Asia/2277.cfm> Past Imperfect
14 [2008) | (C) |ISSN 1711-053X| elSSN 1718-4487
} 
for Responsibility on the 228 Massacre," the public became even more accepting of Chiang being responsible. In a February 2007 survey by Taiwan Thinktank, 61 percent of those surveyed supported blaming Chiang Kai-shek for the incident, while 28 percent disagreed. ${ }^{33}$ The DPP government was quick to remove Chiang's statues from public and military institutions. However, 160| the removal of Chiang also served further to distance Taiwan from China, an important effort in the dream of an independent Taiwan. Although Sun Yat-Sen, the founder of the KMT in China had nothing to do with the 228 Incident, his bronze bust was quietly removed from the main hall of the Presidential Palace on March 14, 2007 and replaced with a potted plant. ${ }^{34}$

Despite the fact that so many people in Taiwan accept that Chiang Kai-shek was responsible for the massacre, they were willing to return the KMT to power. Ma Ying-jeou's victory in the 2008 presidential election did not result in the replacing of these statues, which now decorate a park in Da-hsi, Taoyuan County. Although he had earlier promised to restore the name of Chiang Kai-shek Memorial Hall, he has now agreed to await further research on the subject. It is now clear that the "Research Report for Responsibility on the 228 Massacre" has had quite an impact on Taiwan society, as both the KMT and DPP have both had to accept its outcome to some extent. With Chiang accepted as the antagonist is this narrative, a greater sense of finality exists and the 228 Incident's power over politics is diminished.

\footnotetext{
${ }^{33}$ Shu-ling Ko, "Survey suggests Chiang should take blame for 228," Taipei Times, 8.257, February 26th, 2007.

${ }^{34}$ Shu-ling Ko, "Presidential Office replaces statue of Sun with pot plant," Taipei Times, 15 Mar. 2007

$<$ http://www.taipeitimes.com/News/taiwan/archives/2007/03/15/2003352338

Past Imperfect

14 [2008) | (C) |ISSN 1711-053X| elSSN 1718-4487
} 
This does not indicate an end to the controversy surrounding the 228 Incident. Indeed, in a 2007 conference on the matter, Academia Sinica scholar Chu Hung-yuan (朱浤源) concluded that "the Japanese government is the true culprit," due to its management of colonial Taiwan's economy. ${ }^{35}$ In an analysis far different from either KMT or DPP perspectives, Chu and his colleagues have praised the 1947 military intervention,

finding the violence quite justified. ${ }^{36}$ Although Chu's scholarship has been contested by other academics and the media, his work reminds us that the deeply political mythologization of the 228 Incident is still far from over.

Works Cited

Alexander, Jeffrey C. "Toward a Theory of Cultural Trauma", in Jeffrey C. Alexander, et al, (Eds), Cultural Trauma and Collective Identity, Berkeley: University of California Press, 2004.

Berry, Michael. "Screening 2/28: From a City of Sadness to a March of Happiness", In The Proceedings of Taiwan Imagined and Its Reality -An Exploration of Literature, History, and Culture. Santa Barbara: Center for Taiwan Studies, 2005

Chen Shunxie 陳舜協. “Chu Hung-yuan: Ererba Shijian Yuanxiong shi Riben Zhengfu” 朱浤源：二二八事件元兇是日本政府 (Chu Hung-yuan: The Original Culprits of the 228 Incident were the Japanese Government), 5 Mar. 2007 $<$ news.yam.com/cna/politics/200702/20070227981082.html>

${ }^{35}$ Chen Shunxie 陳舜協, “Chu Hung-yuan: Ererba Shijian Yuanxiong shi Riben Zhengfu” 朱浤源：二二八事件元兇是日本政府 (Chu Hung-yuan: The Original Culprits of the 228 Incident were the Japanese Government), 5 Mar. 2007 $<$ http://news.yam.com/cna/politics/200702/20070227981082.html>

${ }^{36}$ Michael Rand Hoare, "Retrospect and Comparison: The 50th and 60th '228' Anniversary Conferences and Ceremonial in 1997 and 2007 (paper presented to the European Association for Taiwan Studies Conference, Stockholm, April 20/22, 2007). 
Copper, John F.. Taiwan: Nation-State or Province? (4 ${ }^{\text {th }}$ edition). Boulder: Westview Press, 2003.

Ererba Shijian Jinian JijinhuiWeituo二二八事件紀念基金會委託 (228 Incident Remembrance Foundation). Ererba Shijian ZerenGuishu Yanjiu Baogao二二八事件責任歸屬研究報告 (Research report on responsibility for the 228 Massacre). Taipei: Ererba Shijian Jinian Jijinhui二二八事件紀念基金會, 2006.

Hoare, Michael Rand. "Retrospect and Comparison: The 50" th $60^{\text {th }}$ ' 228 ' Anniversary Conferences and Ceremonial in 1997 and 2007. Paper presented to the European Association for Taiwan Studies Conference, Stockholm, 20 Apr. $2007<$ http://www.soas.ac.uk/taiwanstudies/eats/eats2007/38474.pdf>

Hsü, Immanuel C.Y..The Rise of Modern China (6 ${ }^{\text {th }}$ Edition). New York: Oxford University Press, 2000.

Kerr, George. Formosa Betrayed. Boston: Houghton Mifflin Company, 1965.

Ko, Shu-ling. "Chen urges truth of 228 Incident to be remembered," Taipei Times, 29 Apr. 2007

< http://www.taipeitimes.com/News/front/archives/2006/03/01/2003295137>

------.- "Survey suggests Chiang should take blame for 228," Taipei Times, 8.257, (February $26^{\text {th }}, 2007$ ), p 1-3.

----.- "Presidential Office replaces statue of Sun with pot plant," Taipei Times, 15 Mar. 2007

$<$ http://www.taipeitimes.com/News/taiwan/archives/2007/03/15/2003352338

Lai, Zehan, et al, A Tragic Beginning: The Taiwan Uprising of February 28, 1947. Stanford: Stanford University Press, 1991.

Lee Teng-hui. The Road to Democracy: Taiwan's Pursuit of Identity. Tokyo: PHP Institute, 1999.

Mo, Yan-chih. "No Apologies at KMT's 228 Ceremony." Taipei Times, 29 Apr. 2006

<http://www.taipeitimes.com/News/front/archives/2006/02/26/2003294695>

Mobrand, Erik. "Taiwan Remembers Feb. 28 Incident." World Press, 29 Apr. $2006<$ http://www.worldpress.org/Asia/2277.cfm>

Riggs, Fred W.. Formosa Under Chinese Nationalist Rule. New York: The 
Macmillan Company, 1952.

Roy, Denny. Taiwan: A Political History. Ithaca: Cornell University Press, 2003.

Shih Hsiu-chuan. "Hardline Academics Blame Japan for 228 Incident," Taipei Times, 8.258, (February 28th, 2007), p.1.

Spence, Jonathan D.. The Search for Modern China. New York: W.W. Norton and Company, 1999.

Zhu Tianwen 朱天文. Bei qing cheng shi 悲情城市 [City of Sadness], DVD. Directed by Hou Hsiao-hsien 侯孝賢. Taiwan: 3-H Films/Era, 1989.

Past Imperfect 